\title{
Causes of Domestic Violence between Thai Muslim Married Couples in Satun Province
}

\author{
Kasetchai Laeheem ${ }^{1}$ \\ ${ }^{1}$ Faculty of Liberal Arts, Prince of Songkla University, Hatyai, Thailand \\ Correspondence: Kasetchai Laeheem, Faculty of Liberal Arts, Prince of Songkla University, Hatyai, Songkhla \\ 90110, Thailand. E-mail: Lkasetchai@yahoo.com
}

Received: June 24, 2014 Accepted: September 9, 2014 Online Published: October 30, 2014

doi:10.5539/ass.v10n21p89

URL: http://dx.doi.org/10.5539/ass.v10n21p89

\begin{abstract}
The objectives of this qualitative study were to investigate causes of domestic violence between Thai Muslim married couples in Satun Province. The data were collected through in-depth interviews with three groups of key informants in Satun Province consisting of 1) twenty women facing domestic violence who were admitted in Satun Hospital through the One Stop Crisis Center (OSCC), 2) fifteen married husbands and wives using domestic violence recommended by the Community Mosque Committee, and 3) ten religious leaders. To analyze the data, content analysis was performed using logical comparison with concepts, theories, and research coupled with the context. It was found that domestic violence between Thai Muslim married couples in Satun Province stemmed from five important causes. 1) jealousy and suspicions, 2) alcohol and drug abuse, 3) lack of physical and mental readiness for building their own family, 4) lack of activities contributing to caring and understanding in the family, and 5) husbands' values and belief in male dominance.
\end{abstract}

Keywords: cause, domestic violence, Thai Muslim married couple

\section{Introduction}

Domestic violence has long been an important problem in Thai society to which importance has not been given either in terms of solution or prevention even though the problem has been increasingly more severe and affected many related individuals. The reason for this is that Thai society usually regards domestic violence as a personal matter of families that people outside cannot interfere, and as only violation of human rights. That is why domestic violence is a hidden and complicated problem that is difficult to prevent and to solve (Karnkanakul, 1997; Promrak, 2007; Laeheem, 2014). Domestic violence is negative behavior against each other between family members that is more severe than only feeling unhappy or feeling that arises from irregular emotion that has been accumulated including experiences and the thinking process of individuals in response to different environments. Thus, domestic violence can develop from conflict between family members (Malley-Morrison, 2004). Domestic violence is a pattern of acts of injuring the other person physically, violating the person sexually, and mentally hurting between family members, especially husband and wife (Kongsakon \& Pojam, 2008). It is related to conflicts and severe acts against each other of family members which makes it difficult to prevent because some people in society still believe that clashes and conflicts between family members are normal for all families. As a result, the problem is usually managed when conflict has already become violence (Sanprasit, Boonprakob, Kongsakon, \& Intarakamhang, 2011).

Several studies showed that the prevalence of domestic violence between married couples is very high. For example, Kuning (2003) found that 33.6 percent of women in Pattani province, Thailand reported that they had suffered emotional abuse, 25.9 percent had suffered physical abuse, and 36.6 percent had suffered sexual abuse. Archawanitkul and Im-am (2003) reported that 41.0 percent of women in capital Bangkok and a province in Thailand were being abused. More specifically, the study stated that a quarter of these abused women initiated physical assault against their husbands. Both males and females are likely to take actions as aggressors. Sopikul (2006) august that in the past year, about 65.0-70.0 percent of both male and female confessed committing violence acts (male $=65.3$ percent, and female $=69.4$ percent). In accordance with the results, 72.9 percent of the male spouses committed violence acts while 60.2 percent of the female spouses committed violence acts. The incidence of marital violence in the study shows that females committed a greater number of violence acts. Laeheem and Boonprakarn (2014) presented the domestic violence statistics in Thailand of the Centre of One 
Stop Crisis (2011) and the Centre of Violence against Children and Women and Domestic Violence Information (2013), which showed that there were 22,639 cases of women seeking asylum at the One Stop Crisis Center in 2011. Among them, 8,336 cases $(36.82 \%)$ were those with the spouses who assaulted being family members or closely-related persons and 1,950 cases $(8.61 \%)$ being strangers. Besides, it was found that husbands were the persons who assaulted their wife most frequently (5,786 cases, $52.03 \%)$ and such assaults eventually led to divorces (Center of One Stop Crisis, 2011). The frequencies of domestic violence between spouses were rather high during 2010 up to 2013. There were 949 cases of violence in 2010, 1065 cases in 2011, 887 cases in 2012 and 776 cases in 2013. As can be seen, the frequencies did not decrease to the level in 2008 of only 54 cases (Center of Violence against Children and Women and Domestic Violence Information, 2013). Supanichwatana and Laeheem (2014) stated that domestic violence between spouses scenarios reflect the reality that the assault of a wife has continually become more serious in degree, 39.5 percent of wives were physically assaulted by their husbands annually in Thailand.

From reviewing studies related to causes of domestic violence between married couples, it was found that there are many factors related to causes of domestic violence such as being stubborn, hot-tempered, easily get angry, unable to control angriness, suspicions, speaking unsuitably, being worried, reserved, inflexible, gullible, enjoying drinking, having low-income or debt, living in a crowded condition and risk, being with burden in raising many children, depending on the elderly relatives who are not their parents, and having little time for doing activities with other family members (Sanprasit, Boonprakob, Kongsakon, \& Intarakamhang, 2011). Another cause of domestic violence is being physically and mentally unprepared or immature to build a family. Wrong attitudes and values concerning the role of males and females in the family, social and economic crises resulting in weak relationships and misunderstanding, lacking love and care, not accepting behavior of the other party and cannot adjust to each other (Puawongpaet, 1994). Moreover, causes of domestic violence can include differences in character, attitude or personality that individuals have attained from their families. Other caused are financial problems, problems concerning quality of life, problems arising from family members who do not realize their role in the family, and from unfaithfulness of the spouse that leads to physically hurting each other and conflicts that they can no longer maintain the family (Parimutto, 2011).

These problems result in unbalanced families and lead to a variety of complicated problems such as broken families, abandoned children, and the uncared-for elderly. In particular, domestic violence that affects spouses, and physical and mental injuries resulting from divorces are harmful to all parts of society. Every time that violence occurs, it brings about losses to victims who are family members, and such losses include physical, mental, economic and social losses. This can be seen in a study that found that violence against wives incurred an enormous economic burden to society in terms of medical treatment, social welfare, advice provided for injured victims, and implementation of preventive measures, etc (Kanjanakul, 1997). An assault against one's wife is a problem that has a long term effect on children in families where parents use violence against each other. Children can learn and absorb violence through certain training and socialization (Hemmanad, 1990). Parents quarrelling, hurting each other physically can affect children mentally and emotionally and it can affect their other feelings as well as their learning and absorption of violence. Additionally, beating each other connects to children as well (Puawongpaet, 1994). Domestic violence can affect three groups of people. The first group of people affected is women being assaulted. Women assaulted by their husbands are not only injured physically and have to be treated but are also affected mentally with hidden wounds in their hearts that remain there all their life, and most of them are not treated mentally to have self-actualization. The second group of people affected is family members. Domestic violence that males commit against females can affect family members, especially young children and teenagers. They are directly and seriously affected mentally and as a result, they can have negative image of family relationships that further affects their quality of life because it can make them aggressive, roguish, and not attentive to their studies. The third group of people affected is people in society/community. In low-income families, when parents are separated, whether divorced or not divorced, children might run away from home, become homeless, and eventually become either short-term or long-term social problems (Promrak, 2007).

Domestic violence among the Muslim community is considered a complicated humans right issue due to varying legal remedies for women by nation, the extent to which they have support or opportunities to divorce their husbands, cultural stigma to hide evidence of abuse, and inability to have abuse recognized by police or the judicial system (Hajjar, 2004). While domestic violence exists in both Muslim and non-Muslim societies, the position of Islam on the kind treatment of women is very clear as mentioned in the Quran and exemplified through the life and character of the Prophet Muhammad (pbuh). "The nobler among you in the sight of God is the more righteous among you." (Quran, 49:13) It is narrated that the Prophet Muhammad (pbuh) said, "The 
most perfect of believers in belief is the best of them in character. The best of you are those who are the best to their women. And in another tradition, "The best among you are those who are kindest to their wives." The Prophet (pbuh) also taught that a husband's treatment of his wife reflects a Muslim's good character, which in turn is a reflection of his faith. The character of the Prophet Muhammad (pbuh) exemplified how one should be good to his wife. He should smile, not hurt her emotionally or physically, remove anything that will harm her, treat her gently, and be patient with her. He should communicate effectively with her, involve her in decision making and support her in times of difficultly. God instructs men to be nice to their wives and to treat them well to the best of their ability. A devout Muslim should always remember that pleasing his wife is part of faith and earns the pleasure of God, whilst dealing with her unjustly will earn God's anger. The statistics on domestic violence are alarming. The problem exists in both Muslim and non-Muslim societies. The worship of God, which Muslims believe is the sole reason for their existence, is an all-encompassing concept that applies equally to one's relationship with God as well as with His creation. In Islam, one cannot perfect their Worship to God, unless they perfect their relationship with others. The kind treatment of others, including one's spouse, can therefore not be ignored as an obligatory act of Worship and a sign of piety to God. Islam teaches the individual to constantly consider which deeds and behaviors will be pleasing to Allah and to interact with others in way that will be pleasing to Him. As the Prophet Muhammad (pbuh) related, "The best amongst you in the sight of God are those who are the best to their wives." It is through attaining a higher level of God-consciousness that Islamic principles can contribute to the elevation of society. As a believer sincerely contemplates on how his deeds will be viewed by God, he learns to improve his conduct with others, including his spouse (Ali, 1989; Hajjar, 2004; Volunteers associated with Islamic Circle of North America, 2013).

The researcher, therefore, was interested in the problems and considered it was necessary to conduct a study on causes of domestic violence between Thai Muslim married couples in Satun Province. The results of this study would be useful for policy forming, especially on prevention, and problem solving of domestic violence before the problem worsens and the violence is more severe and difficult to solve.

\section{Methods}

The data for this qualitative study were collected through in-depth interviews with three groups of key informants: 1) Twenty women facing domestic violence who were admitted to Satun Hospital through the One Stop Crisis Center (OSCC); 2) Fifteen spouses, who use domestic violence and who were recommended for this study by the Community Mosque Committee; and 3) Ten religious leaders. The data were primarily analyzed and classified into categories according to the research questions. Then content analysis was performed using logical comparisons of concepts, theories, and research reports and context.

\section{Results and Discussion}

This study presents the results of data analysis emphasizing causes of domestic violence and describes the behaviors in using domestic violence and the effects of domestic violence caused by each behavior. From the data analysis, there were five causes of domestic violence between Thai Muslim married couples in Satun Province.

1. Jealousy and suspicions are major and first causes of domestic violence between Thai Muslim married couples. Jealousy and suspicions are usually the beginning of the problem of domestic violence, which begins by showing anger, sarcasm, and use of verbal abuses all the time to make the other party angry. After that they quarrel and severely assaulted each other. Whether husbands or wives are jealous and suspicious, it can end up with physical assaults. Take a case of Mrs. Khoreeyah who said "I am the second wife of the three wives. I love my husband and I feel all the time that he loves the other two wives more than me. So I began to speak sarcastically and so we've scolded, quarreled, and used force to physically hurt each other regularly for 5 years. The latest incident was on December 26, 2013. After a severe quarrel, I used a broom to hit my husband $2-3$ times, and so he kicked and punched me and hit me with his elbows and knees unceasingly. As a result, I had to be hospitalized but after that I went back and lived with him under the same domestic violence". Another case is Mrs. Ranee who said "My husband was extremely jealous and often suspicious that I had another man so sometimes he secretly followed me which gave me stresses and I could not sleep. We quarreled and hurt each other regularly. On December 2, 2013, I had to stay in hospital because he jumped and kicked me on my back and hit me on the head several times and so hard that I got wounded on my head. I finally filed a complaint with the Provincial Islamic Committee to proceed with a claim for a divorce for me".

As seen above, jealousy and suspicions are the origins and important causes of problems for married couples that mix love with pain, sorrow, anger and fright. The state of mind is in doubt, suspicion, worry, and a feeling that the one you love and are attached to must be with you only and that you must keep this person for only yourself 
and never let anyone take him or her away. Therefore, jealousy is a negative feeling that damages relationships and increases the feeling of hatred towards the other person who has become intimate with your loved one (White \& Mullen, 1989). Domestic violence is a two-way problem relationship that neither one party is to blame because very often both parties incite one another with words, gestures, and actions. Domestic violence is hurting each other between or among family members who have built the family with love but they hurt each other because of jealousy (Ua-amnoey, 2002). Jealousy and suspicions are the driving force for domestic violence that happen because of the sudden feeling of resentfulness or such feeling that has accumulated for a long time (Sitdhisoradej, 1999). The situation that leads to most of physical injuries happen suddenly and out of accumulated feeling of jealousy and suspicions, such as a husband is jealous and suspicious that his wife having someone new (Chotiratana, 1994; Straus, 2001). Such feeling can cause a severe conflict and quarrel leading to severe physical assaults in a family making it impossible for the couple to maintain the family (Parimutto, 2011). Thus, family relationships become worse and family members lack understanding among themselves, lack love and care for each other, cannot accept the behavior of each other and cannot adapt themselves to each other. When the family faces such problems and if they do not have suitable problem-solving skills, conflicts will take place, and if accumulating for a long time, it can eventually become domestic violence (Puawongpaet, 1994). When husband and wife cannot adapt to each other, if they face problems that have been suppressed, they can quarrel seriously and begin to use various forms of violence (Holtz \& Safran, 1989; Moser \& Winton, 2002)

2. Alcohol and drug abuse is another cause after jealousy and suspicions for the problem of domestic violence between Thai Muslim married couples in Satun Province. Drinking alcohol and using drugs make people drunk, lose their sense and lose control of themselves, and likely to make wrong decisions. Because drinking alcohol and using drugs are against Islamic principles, wives warn their husbands not to drink and not to use drugs but to change themselves to follow Islamic principles strictly but their husbands never listen and instead, they always scold and hurt their wives physically, especially when they are drunk. They assault their wives severely and with some tools. This can be seen in the case of Mrs. Nureeyah who said "I've been married for 10 years by arranged marriage so I did not know his character, whether he practiced according to the Islamic principles, and whether he drank or used drugs or not. I began to know that he drank alcohol and used amphetamine and marijuana after I had been married with him for 5 years. After he had known that I knew about it, he drank and used drugs openly. I've been extremely stressed out because he has seriously violated religious principles. I've always warned him and asked Allah to bless him and make him a good man and turn back to practice religion strictly. But every time I warn him, he gets angry and then we begin to quarrel and he usually physically injures me such as throwing an alcohol bottle at me and I had a bleeding cut. Once he hit my back and head with a chair and I became unconscious, and sometimes he tramples me. The latest one was last month (December 24, 2013) when we quarreled over the same old problems and he used an iron rod hit me and I had to be hospitalized. Now a related agency has helped us reconcile and taken my husband to attend rehabilitation so that we can return to our happy family life again in the near future". Mrs. Sukanya is another case. She told us "My husband has used amphetamine for five years now. Every time that he uses amphetamine or marijuana or takes mytragynine drinks, he hurts me physically very severely, as if we have not known each other before. He always slaps me, kicks me, and beats me and sometimes I fight back but he is stronger so the more I fight back, the more he hurts me, so I usually choose to run away from him. Then on September 4, 2013, he strangled me, grabbed my head, and pushed it against the floor so hard that my head started to bleed and I became unconscious. My relatives took me to hospital. But until now I still live with him even though the problems of he physically hurting me after using drugs have not been solved". Another case is Mrs. Janjira who reflected the worst incident in her life. She said "My husband always drinks at home and goes out to drink, too and when he's drunk, he starts a quarrel and slaps me and talks about things that have made us quarrel. For example, he blames me for raising our son in such a way that makes him a transgender person and unemployed, not doing household chores, not coming back home regularly, and taking family matters to relatives, etc. It always ends up with he physically hurts me and I sometimes fight back. The latest incident was on December 18, 2013 when he was drunk and hit my head with the bottle he was carrying. The doctor had to give me more than 10 stitches. Now my children and I live with my parents and the religious leader is talking to my husband to get a divorce for me".

As can be seen from the abovementioned cases, another cause of domestic violence between Thai Muslim married couples in Satun Province is alcohol and drug problems. People who drink alcohol and use drugs cannot control their feelings so they feel vigorous and impetuous. Their brain systems cannot work in good co-ordination so they cannot speak clearly, cannot walk in a straight line, and their eyes and brain do not co-ordinate well. Their actions and their decisions can be wrong because they cannot see very well, have blurred visions, feel confused, have severely aggressive behaviors and cannot remember well. Women whose husbands drink alcohol and use drugs while drinking have a chance to be severely assaulted by their husband 3.97 times 
the women whose husbands do not drink (Sarakarn \& Kammanat, 2009). Alcohol and drug abuse is a personal factor that causes domestic violence. People who are addicted to alcohol and drugs usually have aggressive behavior, and see violence as normal and believe that problems must be solved with violence (Holtz \& Safran, 1989; Moser \& Winton, 2002). The rates of domestic violence for women whose husbands use alcoholic drinks and those whose husbands do not use alcoholic drinks are 75.8 percent and 10.7 percent, respectively (Hongthong, 2000). Alcohol use by husbands can predict accurately 66.2 percent of behavior in assaulting wives physically (Klongpayabarn, 1999). Violence against wives and husbands' use of alcohol are significantly related. More women whose husbands drink alcohol regularly are assaulted than those women whose husbands do not drink alcohol (Arpapirom, 2000; Banditwong, 2001). Alcohol and drug abuse is an important cause of quarrels. There are data showing that in families with family members drinking alcohol and using drugs regularly are more likely to have quarrels than those families with family members drinking and using drugs occasionally. 6.2 percent of wives are physically injured in families with husbands drinking alcohol and using drugs regularly. Therefore, families with either husbands or wives drinking alcohol regularly can have the same rate of problem of physically injuring each other. However, wives, when drunk, may be more disadvantageous and more likely than husbands to be assaulted by people in the family (Intarajit \& Karinchai, 1999; Tangkunburibun et al., 2006).

3. Lack of physical and mental readiness and maturity to build a family is another cause of domestic violence. Some women and men are not ready to build a family of their own, especially young married couples who are still teenagers. They should have knowledge and understanding of their roles towards each other as husbands and wives as well as their roles as parents. Moreover, they should be able to control their emotions, to be patient, to forgive, and to earn enough money for the expenses in the family. In many cases, an important cause of domestic violence is the inability to control one's emotions such as a person who is hot-tempered and impetuous. Being stressed because one cannot earn enough money for the family can also lead to quarrels, disputes and physical assaults. In the case of Mr. Abdullah who told us that "When I was 17 years old, I got married with a 15-year-old girl, and at that time I was unemployed. After I got married, I was hired to work on a fishing boat for 200 baht a day, and my wife was a homemaker. The small earnings were not enough for my family so my wife and I were under stress and we often quarreled. We were both short-tempered and young and we often solved the problem using force and were both injured or bruised. Sometimes my wife ran away back to stay with her parents and I always reconciled to her". Another case is Mrs. Ramlah who said "Because my husband and I got married when we were teenagers, and I think that we were not ready to be married because we still lacked emotional maturity, so we often quarreled and physically hurt each other. Last month (February 18, 2014), we quarreled over the expenses in the family and he got so angry that he hit me with a broom and I was severely injured and had to be bedridden for over a month". Mr. Husen's case was another incident. He said, "I was forced by my parents to get married when I was 19 years old. I liked to go places and did not like to stay at home all the time. When I went somewhere, I went for a week or longer, so my wife got very moody and always asked me questions like a policeman questioning a convict, and I was so annoyed. Sometimes I just walked out from home to avoid troubles but other times we physically hurt each other. Most of the time, I slapped and kicked her while she used tools to hurt me like throwing pots and pans at me or hit me with a broom or used a knife to threaten me.

The above cases indicate that Thai Muslim married couples in Satun Province use domestic violence. In some cases, husbands injure their wives while in other cases wives injure husbands. The important cause is that they are young or teenage couples who are not ready physically and mentally for married life, and they lack maturity to build a family of their own at the same time as lacking knowledge and understanding of their roles towards each other. Teenage married couples cannot control their emotions and are not patient enough to remain calm so they often quarrel severely and use violence against one another. This corresponds with studies that found that the causes of conflicts and the use of domestic violence are that the couples are unprepared and unready physically and mentally, and are not mature enough to have a family of their own. Wrong attitudes and values on gender roles, authoritative relationships in the family, socio-economic crisis affect family relationships making family members misunderstand each other, have no love and care, cannot accept behavior of the other, and cannot adapt themselves to each other. When the family faces problems and lacks suitable problem-solving skills, conflicts can happen and if conflicts accumulate for a long time, they can eventually become domestic violence (Puawongpaet, 1994; Oopyokin, 1995; Kongsakon \& Pojam, 2008). The causes of domestic conflicts and domestic violence are differences in characters, attitudes, personalities, training, how the person was brought up, financial problems, problems in quality of life, and problems of not realizing one's own role and responsibility. These causes can lead to severe quarrels in which serious assaults or conflicts can take place and the family status cannot be maintained (Hemmanad, 1990; Pongwech \& Wijitranon, 2000; Parimutto, 2011). 
4. Lack of family activities that contribute to caring for and understanding each other is another cause of domestic violence. Spending time doing activities together in the family is an important foundation for developing and building happy families. Spending time doing activities together is a learning process for understanding each other and it can tighten the relationships. However, from conducting in-depth interviews, it was found that Thai Muslim married couples in Satun Province who use domestic violence do not have time to do activities together. As a result, they feel distant from each other, do not understand, do not have to time to talk, and do not adapt themselves to each other, and they solve problems by quarreling and physically assaulting each other. In the case of Mrs. Salma, she said, "My husband and I have to work hard everyday. We leave home early in the morning. I sell vegetables in the fresh market and my husband delivers goods in different provinces. We have no time for each other and when we have a problem, we quarrel and hit each other. Last week (March 8, 2014) I told him about our son's poor school performance and bad behavior so that we can help solve the problems together but he asked me why I did not take care of our son and teach him because it is a mother's duties to do so. I said it was our duties not just mine. I have to work outside and do house chores while he works only outside the home. We quarreled severely and I was very angry so I hit him with an iron rod and he was wounded and had to stay in hospital for many days". Another case was Mrs. Sulaikho who said, "My ex-husband worked in another province and came home every two weeks and sometimes once a month so we didn't have time for doing activities together with our children even when he came home during holidays. We didn't have time to discuss and talk about things so sometimes I felt suspicious, worried and I really didn't understand him. This made us quarrel and hurt each other physically all the time. The last quarrel was last month (February 11, 2014) we quarreled severely the whole week and then we physically hurt each other severely and he finally asked me for a divorce".

From the above sample cases, it can be seen that when married couples do not have time to do activities together and with their children, they have less opportunities to interact and adapt themselves to each other as well as less understanding and sympathy for one another. They have no time to discuss matters about their family, which is an accumulation of frustrations, suspicions, worries and stress that finally lead to severe quarrels and fights that hurt each other. Straus (2001) found that the cause of domestic violence stems from differences in the husband and wife's activities and interest, insufficient time for each other as a result of focusing on one's own work. This can lead to a lack of care for each other. Moreover, when the husband and wife are free and available at different time, it prevents them from doing activities together. All these accumulate and make them frustrated and unhappy with each other. Puawongpaet, (1994) and Pradabmuk (2003) specify that the causes of the problems are globalization of technology, communication, and socio-economic crisis that affect family relationships in that family members do not understand, love, care, accept behavior, and adapt to each other. Coser (1956), Gells and Straus (1979), and Sukhum (1988) found that relationship intensity between family relationships is related to the severity of their conflict. The severity of conflict between people whose degree of relationship intensity is high will also be higher than that between people who are strangers. This is because people with close relationships try to hide their unpleasant feelings towards one another and when such feelings accumulate enough, they can explode. On the day of an explosion, not only the matter that makes the explosion happen is expressed but also others that have also been suppressed or accumulated. The closer the relationship, the more the anger is shown.

5. The husband's values and belief that "men are family leaders with power and rights over their wives-This is the concept that some men have. They think that they dominate the household and the properties in it, so they have the power to manage all aspects of the family and to control behavior of family members. This concept is another important cause of domestic violence in which the wife is injured by the husband. In the case of Mrs. Salwanee, she said, "My husband always threatens me, orders me and shows his role as the family leader. When I defy, he slaps me and hurt me physically. Sometimes I think I should go away from him and return to live with my parents but I feel sorry for my children, so I have to suffer living with my dictatorial husband". Another case is Mr. Anuwa who said, "I usually order my wife to do what I want her to do because a wife is responsible for house chores and to serve her husband and children. When she cannot work up to my satisfaction, I always hit her with a rod". Another case is Mr. Salman who said, "Wives must be obedient to their husbands; must do according to the orders of their husbands and if they do not, they will be punished severely by their husbands who slap, beat, scold and use sexual violence against them". The last case is Mrs. Rohanee. She said, "My husband always physically hurt me if I cannot satisfy him and cannot do as he orders. For example, he always reminds me to fetch my children from school as soon as school finishes. But one day I went to sell goods in another district and I was two hours late for picking up my children from school, and my children walked home from school by themselves. When I arrived home, my husband slapped me and hit me severely without asking why I was late, and I had to stay in hospital". 
As can be seen from the above four cases, another important cause of domestic violence between Thai Muslim married couples in Satun Province is the concept that the husbands have thinking they dominate and have rights over everything in the family. It is usually an overall concept for the Thai society that believes in patriarchy in which males are stronger and more powerful. It is a belief that emphasizes males' authority and that females are weak, gentle and unreasonable, and thus, males are suitable to be leaders and head of the household while females are only followers. It is believed that it is normal for males to be aggressive and violent because that makes them true men. It is not for females to be aggressive and violent because if they are, then they are not ladies. It is also believed that a good wife must be submissive, not argue with her husband, must be patient, respect and be obedient to him and serve him in all aspects because he is the owner of his wife so he has rights to do anything with her even punish her severely and she has no rights to resist. Other people should not intervene when husbands and wives quarrel because it is normal for them to quarrel or have conflicts just like the tongue and teeth that hit and hurt each other sometimes. If the father beats his children, he has the right to do it without guilt and other people should not pay attention to it. Another belief is that it is normal for married men to have sexual relationships with other women but if married women do it, they commit adultery and they are so bad that no one wants to associate with (Holtz \& Safran, 1989; Siriwattana, 1995; Moser \& Winton, 2002; Archawanitkul, $\&$ Im-am, 2003). The concept that husbands have about their being the head of the family, especially the belief that they own all the properties and have authority to manage everything in the family can bring about domestic violence. This indicates that such society pays no attention to human rights and does not believe that all humans have equal rights but believes that persons with a higher status have more rights, and that women and children have a lower status than men and thus have fewer rights than men. Therefore, they are abused and taken advantage of by men and such society usually takes violence by men as normal and accepts more severe violence (Moser \& Winton, 2002; Songsumpan, 2002; Archawanitkul \& Im-am, 2003; Punamsap, 2005).

\section{Conclusions and Recommendations}

From analyzing the causes of domestic violence between Thai Muslim married couples in Satun Province, five important causes were found as follows.

1. Jealousy and suspicions-These are the main and first causes which begin from losing temper, speaking sarcastically and satirically all the time, which make the other angry. Then they begin to quarrel and hurting each other physically. Thai Muslim married couples should change from being jealous in a bad way to a good way because jealousy can be good if it shows love and care. Being jealous properly can help tighten the relationship and make the relationship last. It can also prevent Thai Muslim spouses from being unfaithful. Thai Muslim married couples should reduce their being jealous and suspicions by reducing suspicious behaviors such as coming home late, not telling where one has been, turning the cell phone off, being out of contact, looking worried or walking away when talking on the phone, not taking a shower before going to bed saying that one has taken it from elsewhere, etc. These are behaviors that make the Thai Muslim spouse jealous and suspicious even though the other is not at all unfaithful. Therefore, being consistent, transparent, and sincere can help reduce jealousy and suspicions of one's Thai Muslim spouse.

2. Alcohol and drug abuse is considered the second cause, after jealousy and suspicions, of domestic violence between Thai Muslim married couples in Satun Province. Drinking alcohol and using drugs make people feel drugged, lose their sense, lose control of themselves, make wrong decisions easily, and above all, it violates Islamic principles. Wives usually warn their husbands that they should stop drinking and using drugs and turn to religious truths but husbands never pay attention but scold and hurt their wives instead. Therefore, related Islamic leaders and Islamic religious organizations should give importance to providing knowledge, understanding of religious principles to Thai Muslim families and making them realize the religious principles. If husbands are religious, the chance for them to drink alcohol and use drug is almost none. This is considered socialization using Islamic principles with emphasis on faith, practice, and ethics and morals, which is one correct way that leads people to behave according to social norms, and Islamic principles that can prevent Thai Muslim married couples from drinking alcohol and using drugs.

3. Lack of physical and mental readiness and maturity to build a family-- Young or teenage married couples, particularly, lack knowledge and understanding of the roles they should play towards each other. They cannot control their emotions, act hastily, lack patience, and do not forgive each other. Therefore, parents, Islamic leaders, and Islamic religious organizations should give importance to consideration of maturity and economic readiness before giving permission for them to marry. If they are not ready, they should wait and get to know each other more. For those who are already married, there should be promotion for them to know and understand their roles towards each other as well as promotion for activities that help make their families happy even though 
presently before getting married, they have to pass a training course on building a happy family accredited by the Provincial Islamic Committee.

4. Lack of family activities that contribute to caring and understanding each other-For married couples who focus on earning money for their living as their main interest and do not give enough importance to doing activities with family members, this could cause a lack of understanding between them and the family relationships could become distant. Therefore, Thai Muslim married couples should always build and cherish their relationships and understanding such as give time to talk to each other consistently, spend the time together efficiently, get to know and learn about each other more than the time before getting married. Most importantly, they must understand, forgive, and cherish their love and always pay close attention to their partner because if they do not, they can become estranged which can eventually lead to problems.

5. The husband's values and belief that men are dominant and authoritative-The belief that men must be the family leader with authority and rights over their wives and all the properties in the household and the rights to manage them and to control behaviors of family members can cause the problem of domestic violence. Therefore, Islamic leaders and Islamic religious organizations must try to eliminate such concepts and values from Thai society and place emphasis on concepts and values that promote human rights and social equality.

The results of this study can help Islamic leaders, Islamic religious organizations, social and human development authorities, and the government sector in forming concrete policies and strategies for promoting and supporting Thai Muslim married couples to behave in accordance with Islamic principles, for example, policy on instilling awareness in Thai Muslim married couples to behave according to the Islamic way of life and following the Prophet, the best role model; policy on Islamic moral training camps to be held regularly and continuously in different communities; policy on organizing activities and training to give knowledge about the religion and practice according to Islamic principles for Thai Muslim married couples; and policy on promoting and developing the family institution to strengthen it so that it can control Thai Muslim married couples and keep them in the Islamic frame of reference, etc.

Thus, if related individuals and organizations could perform their duties as recommended, it is believed that the problem of domestic violence in Thai society would be mitigated.

\section{Acknowledgements}

I would like to thank the Prince of Songkla University for its financial support.

\section{References}

Ali, A. Y. (1989). The Holy Qur'an: Text, translation and commentary. Brentwood, MD: Amana Corporation.

Archawanitkul, K., \& Im-am, W. (2003). Violence against women. Bangkok: Institute for Population and Social, Mahidol University.

Arpapirom, A. (2000). Violent scenes in globalization. Bangkok: Ammarin Printing and Publishing.

Banditwong, P. (2001). Factor determining violence against wives in Banphotphisai, Nakhon Sawan province (Unpublished master's thesis). Silpakorn University, Nakorn Pathom, Thailand.

Center of One Stop Crisis. Statistics of women and children seeking asylum at OSCC. Bangkok: OSCC.

Center of Violence against Children and Women and Domestic Violence Information. (2013). Annual report on domestic violence cases. Bangkok: Ministry of Social Development and Human Security.

Chotiratana, S. (1994). Family violence: A study on case of husbands injuring their wives in Bangkok and the near provinces (Unpublished master's thesis). National Institute of Development Administration, Bangkok.

Coser, L. (1956). The functions of social conflict. New York: The Free Press.

Gelles, R. J., \& Straus R. A. (1979). Determinants of violence in the family: Toward a theoretical integration. In W. R. Burr, R. Hill, F. I. Nye, \& I. L. Reiss (Eds.), Contemporary theories about the family (Vol. 1, pp. 549-581). New York: Free Press.

Hajjar, L. (2004). Religion, state power, and domestic violence in Muslim societies: A framework for comparative analysis. Law and Social Inquiry, 29(1), 1-38. http://dx.doi.org/10.1111/j.1747-4469.2004.tb 00329.x

Hemmanad, H. (1990). Family violence: The case of study low income husbands in municipal areas Muang district, Ubonratchathani province (Unpublished master's thesis). Thammasart University, Bangkok, Thailand. 
Holtz, H. A., \& Safran, M. A. (1989). Education and adult domestic violence in U.S. and Canadian medical schools: 1987-1988. Morbidity and Mortality Weekly Report, 38(2), 17-19.

Hongthong, D. (2000). Selected factors influence domestic violence against woman and the health consequences: Case study among woman in Phayao province (Unpublished master's thesis). Mahidol University, Bangkok, Thailand.

Intarajit, I., \& Karinchai, N. (1999). Women and children: The victim of domestic violence. Bangkok: Institute of Psychology Hot Line.

Kanjanakul, C. (1997). A domestic violence: A study of wife battering (Unpublished doctor's dissertation). Srinakharinwirot University, Bangkok, Thailand.

Klongpayabarn, B. (1999). Family violence: The factor associated with wives violence in Muang district, Srakaeo province (Unpublished master's thesis). Mahidol University, Bangkok, Thailand.

Kongsakon, R., \& Pojam, N. (2008). Family violence. Bangkok: Srinakharinwirot University.

Kuning, M. (2003). Domestic violence and pregnancy loss in Pattani (Unpublished doctor's dissertation). Prince of Songkla University, Pattani, Thailand.

Laeheem, K. (2014). Development of screening inventory for Thai Muslim spouses at risk of domestic violence behaviors in Satun province. Asian Social Sciences, 10(14), 138-144.

Laeheem, K., \& Boonprakarn, K. (2014). Domestic violence behaviors between spouses in Thailand. Asian Social Science, 10(16), 152-159. http://dx.doi.org/10.5539/ass.v10n16p152

Malley-Morrison, K., \& Hines, D. A. (2004). Family violence in a cultural perspective: Defining, understanding, and combating abuse. Thousand Oaks, CA: Sage Publications.

Moser, C., \& Winton. (2002). Violence in the Central American region: Towards an integrated framework for violence reduction. London: Overseas Development Institute.

Oopyokin, P. (1995). The analysis of the problem of domestic violence. STOU Journal, 8(3), 99-107.

Parimutto, A. (2011). Family conflict solution applied from Theravāda Buddhism Dhamma (Unpublished master's thesis). Mahachulalongkornrajavidyalaya University, Bangkok, Thailand.

Pongwech, M., \& Wijitranon, S. (2000). Dissection stalemate: Gender and domestic violence. Bangkok: Gender and Development Research Institute.

Pradabmuk, P. (2003). Family violence: State of the art review and research promoting system in the future. Nontaburi: Health Systems Research Institute.

Promrak, T. (2007). Women and domestic violence: Divorce as the solution (Unpublished master's thesis). Thammasart University, Bangkok, Thailand.

Puawongpaet, S. (1994). Thai family: The problems and solutions. Journal of Public Welfare, 37(6), 20-24.

Punamsap, W. (2005). Problems and solutions of domestic violence (Unpublished master's thesis). Krirk University, Bangkok, Thailand.

Sanprasit, Y., Boonprakob, P., Kongsakon, R., \& Intarakamhang, U. (2011). Domestic violence prevention model with participatory action of families and community: A case study of a community in Pathumthani province. Journal of Behavioral Science, 17(2), 19-36.

Sarakarn, P., \& Kammanat, Y. (2009). Alcohol consumption behavior and husbands' violent acts against their wives. Journal of Health Systems Research, 3(4), 589-597.

Siriwattana, S. (1995). Domestic violent problem: A case study of psychological impact (Unpublished master's thesis). Thammasart University, Bangkok, Thailand.

Sitdhisoradej, P. (1999). Motivating factors accounting for the murder of husbands by their wives (Unpublished master's thesis). Chulalongkorn University, Bangkok, Thailand.

Songsumpan, C. (2002). Violence in Thai society. Political Substances, 23(2), 144-148.

Sopikul, S. (2006). Predicting husband-to-wife and wife-to-husband marital aggression: A study of Thai married persons in an academic institute. Journal of Demography, 22(1), 1-19.

Straus, S. (2001). Contested meanings and conflicting imperatives: A conceptual analysis of genocide. Journal of Genocide Research, 3(3), 349-375. http://dx.doi.org/10.1080/14623520120097189 
Sukhum, P. (1988). Conflict theory. Bangkok: Thammasart University.

Supanichwatana, S., \& Laeheem, K. (2017). Violence against Spouses in Thailand. In $6^{\text {th }}$ International Conference on Humanities and Social Sciences. Faculty of Defence Studies and Management, National Defence University of Malaysia in conjunction with Faculty of Liberal Arts, Prince of Songkla University, pp. 13-18.

Tangkunburibun, S., Sawaengchareon, K., Thongbai, W., Saritsombat, J., \& Chirapan, N. (2006). State of the art reviews: Causes, processes, and mechanisms of alcohol consumption. Bangkok: Thai Health Promotion Foundation and Center for Alcohol Studies

Ua-amnoey, J. (2002). Restorative justice: Relief to domestic violence. Bangkok: Chulalongkorn University.

Volunteers associated with Islamic Circle of North America. (2013). Islam and domestic violence. Piscataway, NJ: The 877-WHY-ISLAM project.

White, G. L., \& Mullen, P. E. (1989). Jealousy: Theory, research and clinical strategies. New York: Guilford Press.

\section{Copyrights}

Copyright for this article is retained by the author(s), with first publication rights granted to the journal.

This is an open-access article distributed under the terms and conditions of the Creative Commons Attribution license (http://creativecommons.org/licenses/by/3.0/). 